\title{
Influence of Azospirillum lectins on a stress-dependent change in the content of low-molecular antioxidants in plants Alen 'kina S.A., Nikitina V.E.
}

Institute of Biochemistry and Physiology of Plants and Microorganisms, Russian Academy of Sciences, Saratov, Russia E-mail:alenkina_s@ibppm.ru

Key message. It was shown that the lectins Azospirillum brasilense Sp7 (epiphyte) and Sp245 (endophyte) with different efficacy changed the content of ascorbate and glutathione in the initial period of exposure to $\left.\mathrm{CuSO}_{4}, \mathrm{CoSO}_{4}, \mathrm{ZnSO}, \mathrm{Pb}_{4} \mathrm{CH}_{3} \mathrm{COO}\right)_{2}$ on the wheat seedling roots.

Keywords: rhizosphere, Azospirillum lectins, wheat roots, low-molecular-weight antioxidants, abiotic stresses

Azospirillum brasilense is a plant-growth-promoting bacterium. Azospirillum colonizes both root surface and inner tissue: A. brasilense Sp245 was found in the root xylem, whereas A. brasilense Sp7 was found on the root surface. Endophytic bacteria are of particular interest, because they can live mutualistically inside plant tissue. The surface lectins of A. brasilense Sp7 (epiphyte) and Sp245 (endophyte) can bind specific carbohydrates, and they ensure the adhesion of the bacteria to the root surface.

We investigated possible effects of the Sp7 and Sp245 lectins on the content of low-molecular-weight antioxidants - ascorbate and glutathione in roots of 4-day-old wheat seedlings. The roots were exposed to salts of heavy metals $\left.-\mathrm{CuSO}_{4}, \mathrm{CoSO}_{4}, \mathrm{ZnSO}_{4}, \mathrm{~Pb}_{(\mathrm{CH}} \mathrm{COO}\right)_{2}$. Spectrophotometry was used to determine the content of ascorbate and glutathione in wheat seedling roots.

Combined effect of the lectins and the heavy metal salts also increased the root content of ascorbate and glutathione. With the Sp7 lectin, the highest increase in the presence of $\mathrm{CoSO}_{4}, \mathrm{ZnSO}_{4}$, and $\mathrm{CuSO}_{4}$ was observed after 60 min of incubation; the effective lectin concentrations were $20 \mu \mathrm{g} \mathrm{ml}-1$ with CoSO 4 Combined effect of the lectins and the heavy metal salts increased the root content of ascorbate and glutathione. and $\mathrm{ZnSO} 4$ and $10 \mu \mathrm{g} \mathrm{ml}-1$ with CuSO 4 . The highest effect, however, was obtained with $\mathrm{Pb}\left(\mathrm{CH}_{3} \mathrm{COO}\right)_{2}$ and $10 \mu \mathrm{g} \mathrm{ml}{ }^{-1}$ of the Sp7 lectin; the incubation time was $30 \mathrm{~min}$. The content of ascorbate increased by $150 \%$, and that of glutathione increased by $200 \%$. With the Sp245 lectin, the picture was the same but in the presence of $\mathrm{Pb}\left(\mathrm{CH}_{3} \mathrm{COO}\right)_{2}$, the effect was maximal at $5 \mu \mathrm{g}$ ml-1 of the Sp245 lectin after $30 \mathrm{~min}$ of incubation. The content of ascorbate increased by $210 \%$, and that of glutathione increased by $250 \%$. With both lectins, the direction of changes in the content of the antioxidants was the same in all cases; yet, the lectins had different levels of activity. These differences may have been caused by the different structures and carbohydrate specificities of the lectins, resulting in differences in the interaction with the plant cell surface, which are of deciding importance for the "switch on" of the subsequent stages.

The Azospirillum lectins are involved in adaptational changes in wheat seedling roots, and this involvement promotes the normal course of metabolism and ensures regulation of the plant-Azospirillum interaction in a wider range of soil and climatic factors. The range of effects of Azospirillum lectins on host plant metabolism is wider than previously thought. Together with the already existing evidence, our present data permit correction of the current views about the mechanisms that govern associative plant-bacterium interactions.

Участие лектинов азоспирилл в стресс-зависимом изменении количества низкомолекулярных антиоксидантов в растениях Аленькина С.А., Никитина В.Е.

Федеральное государственное бюджетное учреждение науки

Институт биохимии и физиологии растений и микроорганизмов Российской академии наук Саратов, Россия

Аннотация. Показано, что лектины Azospirillum brasilense Sp7 (эпифит) и Sp245 (эндофит) с различной эффективностью изменяли содержание аскорбата и глутатиона в начальный период воздействия $\left.\mathrm{CuSO}_{4}, \mathrm{CoSO}_{4}, \mathrm{ZnSO}_{4}, \mathrm{~Pb}_{(\mathrm{CH}} \mathrm{COO}\right)_{2}$ на корни проростков пщенииы.

Ключевые слова: ризосфера, лектины азоспирилл, корни пшеницы, низкомолекулярные антиоксиданты, абиотические стрессы

Azospirillum brasilense - это бактерии, способствующие росту растений. Азоспириллы колонизируют как поверхность корня, так и внутренние ткани. Штамм A. brasilense Sp245 был найден в ксилеме корня, в тоже время штамм A. brasilense Sp7 был обнаружен на поверхности корня. Эндофитные бактерии представляют особый интерес, поскольку они способны мутуалистически жить внутри растительных тканей. Поверхностные лектины A. brasilense Sp7 (эпифит) и Sp245 (эндофит) могут связывать специфические углеводы и обеспечивать адгезию бактерий к поверхности корня.

Мы исследовали возможное влияние лектинов Sp7 и Sp245 на содержание низкомолекулярных антиоксидантов - аскорбата и глутатиона в корнях 4-дневных проростков пшеницы при воздействии солей тяжелых металлов - $\mathrm{CuSO}_{4}, \mathrm{CoSO}_{4}, \mathrm{ZnSO}_{4}$, $\mathrm{Pb}\left(\mathrm{CH}_{3} \mathrm{COO}\right)_{2}$.

Для определения содержания аскорбата и глутатиона в корнях проростков пшеницы использовались спектрофотометрические методы.

Совместное действие лектинов и солей тяжелых металлов увеличило содержание аскорбата и глутатиона в корнях. В случае лектина Sp7 наибольшее увеличение наблюдалось в присутствии $\mathrm{CoSO}_{4}, \mathrm{ZnSO}_{4}$ и $\mathrm{CuSO}_{4}$ после 60 мин инкубацию. Эффективные концентрации лектина составляли 20 мкг/мл - в случае с $\mathrm{CoSO}_{4}$ и $\mathrm{ZnSO}_{4}$ и 10 мкг/мл - в случае с CuSO 4 . Наибольший эффект, однако, был получен в варианте с $\mathrm{Pb}\left(\mathrm{CH}_{3} \mathrm{COO}\right)_{2}$ и концентрации лектина 10 мкг/мл; время инкубации составляло 30 мин. Содержание аскорбата увеличилось на $150 \%$, а глутатиона - на $200 \%$. С лектином Sp245 картина была такой же, но в присутствии $\mathrm{Pb}\left(\mathrm{CH}_{3} \mathrm{COO}\right)_{2}$ эффект был максимальным при концентрации лектина 5 мкг/мл после 30 мин инкубации. Содержание аскорбата увеличилось на $210 \%$, а глутатиона - на $250 \%$. С обоими лектинами направление изменений содержания антиоксидантов было одинаковым во всех случаях, тем не менее, лектины проявляли разные уровни активности. Эти различия могут быть вызваны различной структурой и углеводной специфичностью лектинов, что приводит к различиям во взаимодействии с поверхностью растительных клеток, которые имеют решающее значение для «включения» последующих стадий.

Результаты настоящей работы свидетельствуют об участии лектинов азоспирилл в адаптационных реакциях в корнях проростков пшеницы, что обеспечивает нормальный ход метаболических процессов и регуляцию взаимодействия растений с азоспириллами при абиотических воздействиях. Важным является то, что лектины способны проявлять ростстимулирующий и защитный эффекты в низких концентрациях, то есть в экологически безопасных дозах. Спектр воздействия лектинов Azospirillum на метаболизм растений-хозяев шире, чем предполагалось ранее. Вместе с уже имеющимися данными наши нынешние данные позволяют скорректировать существующие представления о механизмах, которые управляют ассоциативными взаимодействиями растений и бактерий. 